\title{
Contributing Factors to On-Campus Student Organization Involvement
}

\author{
Veronica Veaux, ABD \\ Department of Business Administration \\ Bemidji State University \\ Email: veronica.veau@bemidjistate.edu \\ USA \\ Angie Kovarik, DBA \\ Department of Business Administration \\ Bemidji State University \\ Email: angie.kovarik@ bemidjistate.edu \\ USA \\ Valerie Wallingford, $\mathbf{P h D}$ \\ Department of Business Administration \\ Bemidji State University \\ Email: valerie.wallingford@bemidjistate.edu \\ USA \\ Matthew Splittstoser \\ Bemidji State University \\ Email: hikerguy612@gmail.com \\ USA
}

\section{ABSTRACT}

Well-respected experts of higher education, including those at the National Survey of Student Engagement (NSSE) and founding director Dr. Alexander Astin of the Higher Education Research Institute at UCLA, have demonstrated strong correlations between the amount of time and effort students put into "educationally purposeful activities" outside the classroom (e.g., student organizations) and positive outcomes of student success, such as satisfaction, persistence, and academic achievement (Astin, 1984, 1993, 1999; Berger and Milem,1993; Pascarella and Terenzini, 2005). This study evaluates student involvement in on-campus student organizations. What characteristics are most highly correlated with participation? Based on the results of previous studies, we hypothesized that student engagement in on-campus student organizations is positively correlated with proximity to campus and that the closer a student lives to campus, the more apt they are to be involved with on-campus student organizations. Not only will students living closer to campus be more active with on-campus student organizations, but they are also more likely to be involved with on-campus student organizations directly related to their major. We also hypothesized that female students are more apt to be involved in on-campus student organizations related to their major than males. Original survey results and future research ideas are discussed.

\section{Keywords: Student engagement, campus engagement, student organizations}

\section{Introduction}

Participation in on-campus student organization activities provides college students with important opportunities to apply knowledge from the classroom to the "real world" and develop practical living skills needed after graduation. This study evaluates student engagement in oncampus student organizations and seeks to determine student satisfaction, better understand why students participate in these activities and determine what characteristics are most highly correlated with participation.

Purpose/Research Questions

The purpose of this study was to explore how proximity to campus correlates with on-campus student organization involvement in general and related to your major.
We also wanted to determine if gender plays a role in oncampus student organization involvement within organizations related to the student's major.

Our hypotheses were as follows:

Hypothesis 1 (H1): There will be a positive effect of living closer to campus about on-campus student organization involvement.

Hypothesis 2 (H2): There will be a positive effect of living closer to campus about on-campus student organization involvement directly related to your major.

Hypothesis 3 (H3): There will be a higher rate of participation by females over males in on-campus student organizations related to the student's major. 


\title{
International Journal of Business and Applied Social Science (IJBASS)
}

\author{
E-ISSN: 2469-6501 \\ VOL: 7, ISSUE: 8 \\ August/2021 \\ DOI: http://dx.doi.org/10.33642/ijbass.v7n8p4 \\ (c) (7) \\ https://creativecommons.org/licenses/by/4.0/
}

\section{Literature Review}

\section{Student Engagement}

Mayers et al. (2017) defined student engagement as the relationship between the university and student that includes academic and non-academic facets of the student experience on campus. The 2015 National Survey of Student Engagement (NSSE) found that $61 \%$ of students at the campus studied felt that they were provided opportunities to be socially involved on campus. Of that same group, $75 \%$ chose to attend campus events and/or activities.

Student engagement is very important early on as it increases social integration into campus life. Students that are more socially integrated have higher levels of campus involvement will also have higher success rates academically (Simpson and Burnett, 2017; Mayers et al., 2017). Student engagement and campus involvement also provide students with development opportunities. Those that are more engaged have been shown to have an increased level of first-year success and higher retention rates. It was found that campus involvement had a positive effect on first-year students. (Mayers et al., 2017).

In national surveys, there is clear evidence that student engagement is positively correlated to academic and interpersonal gains (Zilvinskis et al., 2017, p. 895). Boatman and Long (2016) argue, "Student engagement is comprised of three areas of integration: academic integration, social integration, and institutional commitment" (p. 657). Our research is focused on the social integration within on-campus student organizations as it relates to student engagement, specifically through proximity to campus, networking, and personal relationship skills.

\section{Proximity to Campus}

According to the Association of American Colleges and Universities (2018), 13\% of first-year college students live on campus. When we look at the state we studied, according to the 2010 census, 50,444 were living in on-campus housing with 54\% being female. With roughly 260,000 students enrolled, that is around $19.4 \%$ living on campus. More than 1,200 students live on campus at the university we researched, which is approximately $25 \%$ of the campus population.

Researchers stated that the population of students living off-campus is on the rise. On average, $25 \%$ of full-time undergraduates (all years) live on campus (Nelson et al., 2016). It has been found that students living on campus have more time to dedicate to studies and campus activities. Living on campus also invites interaction and engagement. Students that live on campus are more engaged and active within student clubs and organizations. Nelson et al. (2016) stated, there is a lower level of engagement for students that work offcampus and live off-campus as they have fewer opportunities for integration into campus life.

Simpson and Burnett (2017) explained that students living on campus have increased access to campus activities and are therefore more engaged than their peers living off- campus. Off-campus students usually have additional responsibilities and have to find a balance between campus engagement and other obligations such as work, family, transportation, etc. Living on campus in a residence hall also provides additional opportunities to interact with peers and become more involved with campus life. Off campus, students are less likely to be provided these opportunities (Simpson and Burnett, 2017).

\section{College Involvement Related to Gender}

Students who are involved in campus life are more academically, socially, and emotionally engaged. Prior research has pointed to the necessity of building relationships within the college experience as an essential component of persistence and retention or staying in college (Astin et al., 1999; Choate and Smith, 2003; Duggan and William, 2011; Kimbark, et al., 2016; O'Gara et al., 2009).

In general, women tend to value positive social interactions, such as value relationship building more than men (Conner and Davis, 2016) and desiring a sense of community (Roldan et al., 2018). Ro and Kim (2019) found that college women self-report "higher than men regarding communication, teamwork, and leadership skills" (p. 58).

Diniz et al. (2018) found that there were no differences in social interaction between men and women (p. 10). This was contrary to previous studies about college women engaging in positive social interactions more frequently than men (Gibson and Lawrence, 2010; Sax et al., 2005).

\section{College Involvement Related to College Major}

A study by Graunke and Woosley (2005) showed that students who interacted with campus organizations are positively correlated to grade point average (GPA) and a major commitment.

Research on career commitment and college completion rates indicates that student fit with their major is an indication of student success. A study by Womack et al. (2018), suggests "engagement in activities for one's major covaried with increased feelings of commitment to one's major" and students who perceive a fit with their major had higher GPAs and persistence toward graduation.

Methodology

\section{Data collection and analysis}

A two-part data collection process was used. First, an on-campus data management system that provided "active users" data for academic years 2014-2015, 2015-2016, and 2016-2017 were used. Second, in cooperation with the Information Technology Services and University Administration, an original twenty-question survey was created using Qualtrics software. The survey was distributed via university email addresses for all students that met the criteria for the search population. The survey was available for three weeks.

A total of 306 students initiated the questionnaire, with 287 fully completing the survey instrument. Of the 287 students surveyed, 98 were male and 189 were female. This sample included 80 freshmen, 72 sophomores, 92 juniors, 42 
DOI: http://dx.doi.org/10.33642/ijbass.v7n8p4

seniors, and 10 others. The sample size of 287 was portion of the United States. Participants were all 18 years of approximately $9 \%$ of the campus population. age or older and were enrolled in the university at the time of

Participants consisted of full-time students enrolled at data collection.

a 4-year public university located in the Upper Midwest

Participant demographics

\begin{tabular}{|lrlr|}
\hline Gender & $\%$ & Hours Worked Weekly & $\%$ \\
Female & 66 & 0 hours & 24 \\
Male & 34 & $1-10$ hours & 11 \\
Housing & $\%$ & $11-20$ hours & 33 \\
On Campus Residential Halls & 52 & $21-30$ hours & 16 \\
Off Campus/Commuter & 27 & $31-40$ hours & 7 \\
Off Campus Walking-Distance & 21 & Over 40 hours & 2 \\
Class Standing & & $24 / 7$ Resident Advisor & 6 \\
Freshman & 28 & Location of Work & 38 \\
Sophomore & 25 & On-campus & 44 \\
Junior & 32 & Off-campus & \\
Senior & 11 & Both & \\
Other & 3 & & \\
Cumulative GPA & & & \\
Above 4.0 & 0.001 & & \\
$3.6-4.0$ & 36 & & \\
$3.1-3.5$ & 36 & & \\
$2.6-3.0$ & 17 & & \\
$2.1-2.5$ & 0.08 & & \\
Lower than 2.1 & 0.02 & & \\
\hline
\end{tabular}

\section{Discussion/Results}

Chi-Square test was used to determine the association among college students living close to campus and on-campus student organization involvement (either related to the major or any organization). The Chi-Square test was used to determine the association between gender and student involvement in organizations related to the student's major.

\section{Chi-Square Test via Cross tabulation 1}

A Cross-Tabulation and Chi-Square Test suggests a correlation between living distance from campus and involvement in on-campus student organizations, where the closer one lives to campus, the more likely they were to be involved in campus activities. With a p-value of 0.007409 and 9.81 degrees of freedom, the result is significant at $p<0.01$.

\begin{tabular}{|c|l|c|}
\hline \multicolumn{2}{|l|}{$\begin{array}{l}\text { Hypothesis 1 (H1): There will be a positive effect } \\
\text { of living closer to campus in relation to on- } \\
\text { campus student organization involvement. }\end{array}$} & $\begin{array}{c}\text { Were you involved in } \\
\text { any BSU student } \\
\text { organizations last year? }\end{array}$ \\
\hline \multirow{2}{*}{$\begin{array}{c}\text { How close to BSU did } \\
\text { you live last year? }\end{array}$} & Chi Square & 9.81 \\
\cline { 2 - 3 } & Degrees of Freedom & 2 \\
\cline { 2 - 3 } & p-value & 0.01 \\
\hline
\end{tabular}

\section{Chi-Square Test via Cross tabulation 2}

your major, where the closer one lives to campus, the more

A Cross-Tabulation and Chi-Square Test suggest a likely they are involved in on-campus student organizations correlation between living distance from campus and student related to their major. With a p-value of 0.069599 and 5.33 involvement in on-campus student organizations related to degrees of freedom, the result is significant at $\mathrm{p}<0.10$.

\begin{tabular}{|c|c|c|}
\hline \multicolumn{2}{|c|}{$\begin{array}{l}\text { Hypothesis } 2(\mathrm{H} 2) \text { : There will be a positive effect } \\
\text { of living closer to campus in relation to on- } \\
\text { campus student organization involvement } \\
\text { directly related to your major. }\end{array}$} & $\begin{array}{c}\text { Was this student } \\
\text { organization related to } \\
\text { your major? }\end{array}$ \\
\hline \multirow{3}{*}{$\begin{array}{c}\text { How close to BSU did } \\
\text { you live last year? }\end{array}$} & Chi Square & 5.33 \\
\hline & Degrees of Freedom & 2 \\
\hline & $\mathrm{p}$-value & 0.07 \\
\hline
\end{tabular}




\author{
E-ISSN: 2469-6501 \\ VOL: 7, ISSUE: 8 \\ August/2021 \\ DOI: http://dx.doi.org/10.33642/ijbass.v7n8p4 \\ (c) (i) \\ https://creativecommons.org/licenses/by/4.0/
}

\section{Chi-Square Test via Cross tabulation 3}

A Cross-Tabulation and Chi-Square Test suggested a correlation between gender and student involvement in oncampus student organizations related to your major, where females are more likely to be involved in on-campus student organizations related to their major. With a p-value of 0.089131 and 2.89 degrees of freedom, the result is significant at $\mathrm{p}<0.10$.

\begin{tabular}{|c|c|c|}
\hline \multicolumn{2}{|c|}{$\begin{array}{l}\text { Hypothesis } 3(\mathrm{H} 3) \text { : There will be a higher rate of } \\
\text { participation by females over males in on- } \\
\text { campus student organizations related to the } \\
\text { student's major. }\end{array}$} & $\begin{array}{l}\text { Was this organization } \\
\text { related to your major? }\end{array}$ \\
\hline \multirow{3}{*}{ What is your gender? } & Chi Square & 2.89 \\
\hline & Degrees of Freedom & 1 \\
\hline & $\mathrm{p}$-value & 0.09 \\
\hline
\end{tabular}

The results of the study are in line with the three formulated hypotheses. The results for the first crosstabulation show that students living in closer proximity to campus are more likely to be involved in on-campus student organizations which directly relates to the literature. Nelson et al. (2016) found that living on-campus invites interaction and engagement. Students that live on campus are more engaged and active within student clubs and organizations. The results from the second cross-tabulation echo results from the first.

The results from the third cross-tabulation showed that there is a relationship between gender and student involvement in on-campus student organizations related to the student's major at the university we studied. Female students were more likely to be involved in student organizations related to their major than males. However, the literature review indicated there was not a relationship between student organizations and gender. This research showed that women are more likely to be involved in on-campus student organizations when the organization is related to their major.

\section{Limitations}

The list of current users may have been outdated and therefore may have not given us the most up-to-date student records. Another limitation would be that we only surveyed students that were currently active in the university's data management system. There may have been other users that were not registered in the system at the time of data collection. Future Research
The literature review indicated there was not a relationship between student organizations and gender. This research showed that women are more likely to be involved in on-campus student organizations when the organization is related to their major. Future research may explore students from a larger population to determine if gender differences within the involvement of on-campus organizations related to the major extend beyond the students surveyed in the Upper Midwest.

We did not analyze whether leadership roles differed between men and women, however, this may be an area of further exploration in clubs and organizations in the Upper Midwest. Rosch et al., (2015) found no difference in the way students behave in leadership roles within student organizations.

\section{Conclusion}

Rust et al. (2015) mentioned that a student's level of involvement in college is directly related to the level of engagement and motivation that a student will have for college experiences including on-campus activities like club and organization involvement.

Students in the Upper Midwestern college surveyed in this study found that students were more engaged in oncampus student organizations when they lived closer to campus. Female students were more likely to be involved in on-campus student organizations related to their major compared to men.

\title{
References
}

Association of American Colleges \& Universities. (2018, November). Misconceptions about today's college students. https://www.aacu.org/aacu-news/newsletter/2018/november/facts figures\#: :text=While\%2062\%20percent\%20of\%20Americans, actually\%20does\%2C\%20the\%20report\%20said

Astin, A. (1984). Student involvement: A developmental theory for higher education. Journal of College Student Development, 40(5), 518-529.

http://chawkinson.pbworks.com/w/file/fetch/122997693/Student_Involvement_A_Development_Theory_for_Highe.pdf

Astin, A. W. (1993). Four critical years revisited: Effects of college on beliefs, attitudes, and knowledge. San Francisco, CA: Josey-Bass.

Astin, A., Sax, L., \& Avalos, J. (1999). Long-term effects of volunteerism during the undergraduate years. Review of Higher Education, 22(2), 187-202. 


\title{
International Journal of Business and Applied Social Science (IJBASS)
}

\author{
E-ISSN: 2469-6501 \\ VOL: 7, ISSUE: 8 \\ August/2021 \\ DOI: http://dx.doi.org/10.33642/ijbass.v7n8p4 \\ (c) (i) \\ https://creativecommons.org/licenses/by/4.0/
}

Bemidji State University Department of Housing \& Residential Life. (n.d.). Housing. https://www.bemidjistate.edu/studentlife/housing/

Berger, J.B., \& Milem, J.F. (1993). The role of student involvement and perceptions of integration in a casual model of student persistence. Research in Higher Education, 40(6), 641-664.

Boatman, A., \& Long, B. T. (2016). Does financial aid impact college student engagement? Evidence from the Gates Millenium Scholars Program. Research in Higher Education, 57(6), 653-681. https://www.jstor.org/stable/43920070

Choate, L., \& Smith, S. (2003). Enhancing development in the 1st year college student success courses: A holistic approach. Journal of Humanistic Counseling, Education \& Development, 42(2), 178.

https://doi.org/10.1002/j.2164-490X.2003.tb00005.x

Conner, T., \& Davis, K. (2016). Do women value the domains of leadership differently than men? Advancing Women in Leadership, 36, 49-53. http://advancingwomen.com/awl/awl_wordpress/

Diniz, A.M., Alfonso, S., Araujo, A. M., Deano, M., Costa, A. R., Conde, A., \& Almeida, L. S., (2018). Gender differences in first-year college students' academic expectations. Studies in Higher Education, 43(4), 689-701.

https://doi.org/10.1080/03075079.2016.1196350

Duggan, M., \& William, M. (2011). Community college student success courses: The student perspective. Community College Journal of Research and Practice, 35(1-2), 121-134. https://doi.org/10.1080/10668926.2011.525185

Graunke, S. S., \& Woosley, S. A. (2005). An exploration of the factors that affect the academic success of college sophomores. College Student Journal, 39(2), 367-376.

Kimbark, K., Peters, M. L., \& Richardson, T. (2016). Effectiveness of the student success course on persistence, retention, academic achievement, and student engagement. Community College Journal of Research and Practice, 1-15. http://dx.doi.org/10.1080/10668926.2016.1166352

Mayers, R.F., Wilson, A.W., \& Potwarka, L.R. (2017). Moderating effects of campus recreation participation in the relationship between grade point average and first-year student engagement: An exploratory study. Recreational Sports Journal, 41(2), 101-110. https://doi.org/10.1123/rsj.2016-0021

Minnesota Office of Higher Education. (n.d.). Facts about student housing: How many students live in college dormitories? https://www.ohe.state.mn.us/mPg.cfm?pageID=1397

National Survey of Student Engagement. (2015). NSSE 2015 Engagement Indicators: Bemidji State University. https://www.bemidjistate.edu/offices/research-effectiveness/wp-content/uploads/sites/53/2015/04/NSSE15-EngagementIndicators-Bemidji.pdf

Nelson, D., Misra, K., Sype, G.E., \& Mackie, W. (2016). An analysis of the relationship between distance from campus and GPA of commuter students. Journal of International Education Research 12(1), 37-45. https://files.eric.ed.gov/fulltext/EJ1088600.pdf

O'Gara, L., Karp, M., \& Hughes, K. (2009). Student success courses in the community college. An exploratory study of student persepctives. Community College Review, 36(3), 195-218. https://doi.org/10.1177/0091552108327186

Pascarella, E.T., \& Terrenzini, P.T. (2005). How college effects students: A third decade of research. San Francisco, CA: JoseyBass.

Ro, H. K., \& Kim, S. (2019). College experiences and learning outcomes of women of color engineering students in the United States. International Journal of Gender, Science and Technology, 11(1), 55-82.

http://genderandset.open.ac.uk/index.php/genderandset/article/viewFile/649/1030

Roldan, W., Hui, J. S., \& Gerber, E. M. (2018). University makerspaces: Opportunities to support equitable participation for women in engineering. International Journal of Engineering Education, 34, 751-768.

https://cpb-us-e1.wpmucdn.com/sites.northwestern.edu/dist/3/3481/files/2012/12/Gerber_UniversityMakerspaces-

Opportunities-to-Support-Equitable-Participation-for-Women-in-Engineering.pdf

Rosch, D. M., Collier, D., \& Thompson, S. E. (2015). An exploration of students' motivation to lead: An analysis by race, gender, and student leadership behaviors. Journal of College Student Development, 56(3), 286-291.

https://doi.org/10.1353/csd.2015.0031

Rust, V., Dhanatya, C., Furuto, H.L., \& Kheiltash, O. (2015). Student involvement as predictive of college freshman plans to study abroad. The Interdisciplinary Journal of Study Abroad 15(1), 1-16. https://doi.org/10.36366/frontiers.v15i1.213

Simpson, D.B., \& Burnett, D. (2019). Commuters versus residents: The effects of living arrangement and student engagement on academic performance. Journal of College Student Retention: Research, Theory, \& Practice, 21(3), 286-304.

https://doi.org/10.1177/1521025117707516 
Wessel, J. L., Ryan, A., \& Oswald, F. L. (2008). The relationship between objective and perceived fit with academic major, adaptability, and major-related outcomes. Journal of Vocational Behavior, 72, 363-376. https://doi.org/10.1016/j.jvb.2007.11.003

Womack, A., Leuty, M. E., Bullock-Yowell, E., \& Mandracchia, J. T. (2018). Understanding commitment: Relations between major commitment, satisfaction, involvement, fit, university commitment, and intention to quit. Journal of Career Development, 45(2), 166-182. https://doi.org/10.1177/0894845316676904

Zilvinskis, J., Masseria, A. A., \& Pike, G. R. (2017). Student engagement and student learning: Examining the convergent and discriminant validity of the revised national survey of student engagement. Research in Higher Education, 58, 880-903. https://doi.org/10.1007/s11162-017-9450-6 